\title{
Dampak Pandemi Covid-19 Terhadap Ekonomi Masyarakat di Nusa Tenggara Barat
}

\author{
Rosiady Husaenie Sayuti ${ }^{1}$ dan Siti Aisyah Hidayati \\ Universitas Mataram
}

\begin{abstract}
The purpose of this research is to find out the economic impact of the Covid-19 Pandemic on the people of NTB. Community life has changed since the implementation of Large-Scale Social Restrictions (PSBB) by the Government. These changes are felt in various areas of the economy, namely income, employment, expenditure and the purchasing system carried out by the community. This research uses descriptive quantitative method. Descriptive research is research conducted with the aim of describing the conditions that took place when the research was conducted. Thus this research is able to clearly portray the economic impact experienced by the people of NTB due to the Covid-19 pandemic. Data collection is carried out using the Google Form tool which is distributed through various existing social media facilities, such as WhatsApp Groups, Facebook, and Twitter. The data scale used is the Likert Scale. Respondents in this study were individuals, namely the people of West Nusa Tenggara. The sample used in this study were 342 respondents. The results showed that most respondents felt the impact of the Covid 19 pandemic from an economic perspective. This is indicated by the answers of respondents who mostly stated that their income received had decreased but could still meet their daily needs, limited employment opportunities, increased expenditure and was dominated by the purchase of foodstuffs. Purchases made online are the choice of respondents. The conclusion of this study shows that this pandemic has a significant effect on people's lives, both those with civil servant and non-PNS backgrounds and those who live in rural and urban areas.
\end{abstract}

Keywords: Covid-19 Pandemic, PSBB, Economic Impact, NTB

\begin{abstract}
Abstrak
Tujuan Penelitian ini adalah untuk mengetahui dampak ekonomi masyarakat NTB sebagai akibat adanya Pandemi Covid-19. Kehidupan masyarakat menjadi berubah sejak diberlakukannya Pembatasan Sosial Berskala Besar (PSBB) oleh Pemerintah. Perubahan tersebut dirasakan diberbagai bidang ekonomi, yaitu pendapatan, lapangan pekerjaan, pengeluaran dan sistem pembelian yang dilakukan oleh masyarakat. Penelitian ini menggunakan metode kuantitatif deskriptif. Penelitian deskriptif merupakan penelitian yang dilakukan dengan tujuan menggambarkan kondisi yang berlangsung saat penelitian dilakukan. Dengan demikian penelitian ini mampu memotret secara jelas bagaimana dampak ekonomi yang dialami masyarakat NTB akibat pandemi Covid-19. Pengambilan data dilakukan dengan menggunakan alat bantu google form yang disebarkan melalui berbagai sarana media sosial yang ada, seperti WhatsApp Grup, Facebook, dan Twitter. Skala data yang digunakan yaitu Skala Likert. Responden dalam penelitian ini adalah individu yaitu masyarakat Nusa Tenggara Barat. Sampel yang digunakan dalam penelitian ini sebanyak 342 responden. Hasil penelitian menunjukkan sebagian besar responden merasakan dampak pandemi covid 19 dilihat dari sisi ekonomi. Hal ini ditunjukkan oleh jawaban responden yang sebagian besar menyatakan pendapatan yang diterima mengalami penurunan tetapi masih bisa mencukupi kebutuhan sehari-hari, lapangan pekerjaan menjadi terbatas, pengeluaran menjadi lebih besar dan didominasi oleh pembelian bahan makanan. Pembelian yang dilakukan melalui online menjadi pilihan dari responden. Kesimpulan penelitian ini menunjukkan bahwa pandemi ini berpengaruh signifikan terhadap kehidupan masyarakat, baik mereka yang berlatar belakang PNS maupun non PNS dan mereka yang tinggal di perdesaan dan perkotaan.
\end{abstract}

Kata Kunci : Pandemi Covid-19, PSBB, Dampak Ekonomi, NTB

\footnotetext{
${ }^{1}$ sayuti@unram.ac.id
} 


\section{Pendahuluan}

Tahun 2020 dunia digemparkan dengan munculnya Virus yang dapat menyebar dengan cepat melalui udara, virus ini dikenal dengan sebutan Coronavirus. Coronavirus merupakan salah satu virus yang serupa dengan common cold atau pilek yang dapat menyebabkan penyakit ringan hingga serius. Virus Corona diidentifikasi berasal dari Kota Wuhan di China pada bulan Desember 2019. Virus tersebut memiliki nama ilmiah Covid-19. Efek yang dirasakan akibat Covid-19 berupa flu ringan hingga flu yang sangat serius setara atau bahkan lebih parah dari Mers-CoV dan Sars- CoV (Kirigia \& Muthuri, 2020). Virus ini disebut sebagai Covid-19 atau Corona Virus Disease yang muncul pada tahun 2019. Dalam beberapa bulan virus ini sudah menyebar keseluruh belahan dunia hingga teridenfitikasi di Indonesia pada bulan Maret 2020 (Nursalim, 2020; Sayuti, 2020; Azimah, 2020).

Dengan munculnya Covid-19 pemerintah Indonesia mulai menegaskan bahwa masyarakat di himbau untuk tidak melakukan aktivitas di luar rumah upaya untuk menghindari meningkatnya penyebaran Covid-19. Berbeda dengan negara lain yang melakukan lockdown, pemerintah Indonesia dengan kebijakan social distancing dan PSBB atau Pembatasan Sosial Berskala Besar diharapkan dapat mengurangi dampak krisis ekonomi (Nasution, 2020; Kickbusch, 2020). Namun meskipun begitu kebijakan ini mempengaruhi aktivitas-aktivitas ekonomi masyarakat di Indonesia dengan dibatasinya ruang gerak masyarakat, belum lagi banyaknya karyawan yang harus dirumahkan bahkan hingga diberhentikan dalam pekerjaannya oleh perusahaan-perusahaan dengan alasan untuk menutup kerugian yang terus membesar (Honoatubun, 2020).

Lebih lanjut, Damuri dan Hirawan (2020) menyatakan kasus penyebaran Covid-19 ini selanjutnya dapat dilihat dari dua sudut pandang ekonomi yang berbeda, yaitu permintaan dan penawaran. Dari sisi permintaan, kondisi pandemi Covid-19 jelas akan mengurangi sektor konsumsi, kegiatan perjalanan dan transportasi, serta peningkatan biaya transportasi dan perdagangan. Sedangkan dari sisi penawaran, kemungkinan besar yang terjadi adalah terkontraksinya produktivitas pekerja/buruh, penurunan investasi dan kegiatan pendanaan, serta terganggunya rantai pasokan global (global value chain). Dari sisi konsumsi, pola konsumsi masyarakat akibat penyebaran Covid-19 secara otomatis akan berubah. Masyarakat akan cenderung untuk tidak melakukan kegiatan perjalanan atau pariwisata dan lebih cenderung meningkatkan konsumsi pada barang-barang kebutuhan pokok yang dianggap penting sebagai antisipasi terjadinya pembatasan pergerakan manusia. Secara keseluruhan, tingkat konsumsi akan cenderung turun karena harga yang terdistorsi akibat mahalnya biaya transportasi dan logistik barang. Sementara itu, dari sisi produksi, beberapa sektor utama di Indonesia juga akan terdampak akibat penyebaran Covid-19, khususnya industri pengolahan (manufaktur). Kontribusi sektor ini cukup signifikan terhadap ekonomi Indonesia (19-20 persen) dan produk yang berasal dari industri pengolahan juga menyumbang secara signifikan terhadap total ekspor Indonesia, yaitu di atas 70 persen. Kinerja industri manufaktur di Indonesia kemungkinan akan melambat seiring dengan meningkatnya kasus Covid-19 ini. 
McKensey pada salah satu artikelnya, memprediksi pertumbuhan ekonomi global akan melambat sebesar 2,2 persen atau 1,8 persen, jauh meleset dari prediksi awal. (Craven et al., 2020). Bahkan IMF juga memberikan prediksi ekonomi global akan menurun tajam dari perkiraan awal menjadi berada pada angka minus 3 persen. (Kemenkeu.go.id, n.d.-c). Sebagai negara yang memiliki jumlah kasus Covid-19 yang cukup signifikan, Indonesia memproyeksi pertumbuhan ekonomi akan mengalami penurunan sebesar 2,3 persen dari prediksi awal sebesar 5,04 persen (Lipi.go.id, 2020). Bahkan dalam skenario terburuk, Menteri Keuangan Indonesia Sri Mulyani menyebutkan pertumbuhan ekonomi bisa berada diangka minus 0,4 persen (VOAIndonesia, n.d.). Dampak ini juga dirasakan oleh seluruh lapisan masyarakat bahkan disemua daerah di Indonesia, begitu juga di NTB (Dani, 2020).

Nusa Tenggara Barat mengidentifikasi Covid-19 pada pertengahan bulan Maret atau lebih tepatnya, pada tanggal 17 Maret 2020. Munculnya pasien Covid-19 pertama di NTB gubernur Zulkieflimansyah menyarankan masyarakat NTB untuk tetap tenang, hindari keramaian, menjaga kesehatan dengan pola hidup bersih, dan mengurani aktvitas diluar rumah. (Tempo, 2020). Melihat reaksi gubernur NTB dipandang kurang tegas pada kebijakannya di awal sehingga penyebaran Covid19 dengan cepat meningkatkan angka positif di NTB. Selanjutnya dengan meningkatnya angka positif kebijakan pemerintah NTB semakin dipertegas dengan pemberlakuan PSBB atau Pembatasan Sosial Berskala Besar. Hal ini tentu berdampak pada ekonomi masyarakat NTB yang banyak mengandalkan aktivitas ekonomi secara langsung.

Oleh karena itu berdasarkan permasalahan tersebut maka penelitian ini penting dilakukan dalam rangka melihat dampak pandemi Covid-19 terhadap kehidupan ekonomi masyarakat NTB. Beberapa indikator yang dilihat pada penelitian ini antara lain penurunan pendapatan, lapangan pekerjaan, kemampuan masyarakat dalam memenuhi kebutuhan hidupnya, pengeluaran, kehidupan ekonomi masyarakat terkait dengan belanja online, pemenuhan kebutuhan dengan melihat pembelian makanan, dan yang terakhir efisiensi dalam pengeluaran.

Pengertian perubahan sosial menurut Gillin dan Gillin (1950) adalah perubahan yang terjadi sebagai suatu variasi dari cara hidup yang telah diterima karena adanya perubahan kondisi geografi, kebudayaan material, komposisi penduduk, ideologi, maupun adanya difusi atau penemuan-penemuan baru dalam masyarakat. Penerapan PSBB selama masa pandemi Covid-19 mengakibatkan perubahan sosial di masyarakat dan menimbulkan dampak secara ekonomi. Dampak ekonomi dijelaskan oleh Stynes (Disbudpar Banten, 2013 : 20) dikelompokkan dalam tiga indikator, (1) direct effect meliputi penjualan, kesempatan kerja, pendapatan pajak, dan tingkat pendapatan, (2) indirect effect, meliputi perubahan tingkat harga, perubahan mutu dan jumlah barang dan jasa,perubahan dalam penyediaan properti dan variasi pajak, serta perubahan sosial dan lingkungan, (3) induced effects, yaitu pengeluaran rumah tangga, dan peningkatan pendapatan. Selain itu dampak ekonomi juga dijelaskan oleh Cohen (Dwi, 2015 : 21) terdiri dari, (1) dampak terhadap pendapatan, (2) dampak terhadap 
aktivitas ekonomi, (3) dampak terhadap pengeluaran. Dari sini lebih diperjelas bahwa dampak ekonomi dijelaskan sebagai akibat dari suatu perubahan yang terjadi dilingkungan.

Teori lain yang juga mendukung penelitian ini yaitu Teori Fungsional Struktural yang pencetusnya adalah Talcott Parson. Asumsi dasar dari Teori Fungsionalisme Struktural, salah satu paham atau prespektif di dalam sosiologi yang memandang masyarakat sebagai satu sistem yang terdiri dari bagian-bagian yang saling berhubungan satu sama lain dan bagian yang satu tidak dapat berfungsi tanpa adanya hubungan dengan bagian yang lainnya. Kemudian perubahan yang terjadi pada satu bagian akan menyebabkan ketidak seimbangan dan pada giliranya akan menciptakan perubahan pada bagian lainya. Perkembangan fungsionalisme didasarkan atas model perkembangan sistem organisasi yang di dapat dalam biologi, asumsi dasar teori ini ialah bahwa semua elemen harus berfungsi atau fungsional sehingga masyarakat bisa menjalankan fungsinya dengan baik. (Raho, 2007)

Masyarakat terintegrasi atas dasar kesepakatan dari para anggotanya akan nilai- nilai kemasyarakatan tertentu yang mempunyai kemampuan mengatasi perbedaan- perbedaan sehingga masyarakat tersebut dipandang sebagai suatu sistem yang secara fungsional terintegrasi dalam suatu keseimbangan. Dengan demikian masyarakat adalah merupakan kumpulan sistem-sistem sosial yang satu sama lain berhubungan dan saling ketergantungan (Grathoff,2000). Menurut pandangan ini, masalah utama adalah bagaimana cara individu memotivasi dan menetapkan diri pada posisi mereka yang "tepat". Dalam sistem stratifikasi, hal ini dapat diturunkan menjadi dua masalah. Pertama, bagaimana cara masyarakat menanamkan kepada individu yang "tepat" itu keinginan untuk mengisi posisi tertentu? Kedua, setelah individu berada pada posisi yang tepat, lalu bagaimana cara individu menanamkan keinginan kepada mereka untuk memenuhi persyaratan posisi mereka (Ritzer, 2010)

Fungsi, dalam hal ini, dikaitkan sebagai segala kegiatan yang diarahkan kepada memenuhi kebutuhan atau kebutuhan-kebutuhan dari sebuah sistem. Ada empat persyaratan mutlak yang harus ada supaya termasuk masyarakat bisa berfungsi. Keempat persyaratan itu disebutnya AGIL. AGIL adalah singkatan dari Adaption, Goal, Attainment, Integration, dan Latency. Demi keberlangsungan hidupnya, maka masyarakat harus menjalankan fungsi-fungsi tersebut, yakni:

1. Adaptation (Adaptasi): sebuah sistem harus menanggulangi situasi eksternal yang gawat. Sistem harus menyesuaikan diridengan lingkungan dan menyesuaikan lingkungan itu dengan kebutuhannya.

2. Goal Attainment (Pencapain tujuan): sebuah sistem harus mendefinisikan dan mencapai tujuan utamanya.

3. Integration (Integrasi): sebuah sistem harus mengatur antarhubungan bagian-bagian yang menjadi komponennya. Sistem juga harus mengelola antar hubungan ketiga fungsi penting lainnya (A,G,I,L). 
4. Latency (pemeliharaan pola): sebuah sistem harus memperlengkapi, memelihara dan memperbaiki, baik motivasi individual maupun pola-pola kultural yang menciptakan dan menopang motivasi.

Munculnya Pandemi Covid-19 juga masuk ke dalam struktur ekonomi masyarakat sehingga mempengaruhi kehidupan ekonomi masyarakat NTB. Teori struktural fungsional melihat sebuah struktur dalam masyarakat yang memiliki fungsi dan peran masing-masing dan saling berkaitan satu dengan yang lain. Munculnya suatu permasalahan di suatu bidang akan mempengaruhi bidang yang lain. Covid-19 merupakan suatu permasalahan dalam bidang medis namun dampaknya terjadi hingga sistem ekonomi masyarakat. Oleh karena itu struktur ekonomi mulai beradaptasi dengan suatu maslah yang terjadi, munculnya disfungsi membuat kehidupan ekonomi masyarakat berubah (Dani, 2020; Kirigia, 2020). Dalam menilai hal tersebut maka penelitian ini melihat indikator-indikator yang berpengaruh dalam masa Pandemi antara lain, penurunan pendapatan, lapangan pekerjaan, kemampuan masyarakat dalam memenuhi kebutuhan hidupnya, pengeluaran, kehidupan ekonomi masyarakat terkait dengan belanja online, pemenuhan kebutuhan dengan melihat pembelian makanan, dan yang terakhir efisiensi dalam pengeluaran.

\section{Metode Penelitian}

Jenis penelitian yang digunakan oleh peneliti adalah kuantitatif deskriptif. Menurut Sugiyono (2018) penelitian kuantitatif deskriptif merupakan salah satu jenis penelitian yang spesifikasinya adalah sistematis, terencana, dan terstruktur dengan jelas sejak awal pembuatan desain penelitian. Sedangkan penelitian ini menggunakan pendekatan deskriptif dengan tujuan menggambarkan kondisi yang berlangsung saat penelitian dilakukan. Dengan demikian penelitian ini mampu memotret secara jelas bagaimana dampak ekonomi yang dialami masyarakat NTB akibat pandemi Covid-19. Ghozali (2011) menyatakan metode kuantitatif dijelaskan sebagai pada metode penelitian yang menganut paham positivism. Metode pengambilan sampel dilakukan dengan perhitungan teknik sampel tertentu yang sesuai. Teknik yang digunakan untuk meneliti pada populasi atau sampel tertentu, proses mengumpulkan data dengan instrumen penelitian dan analisis data bersifat statistik/kuantitatif. Pada Penelitian ini menggunakan Non-Probability Sampling yang merupakan kombinasi dari Convenience, Voluntary dan Snowball Sampling untuk mendapatkan respon partisipasi sebanyak-banyaknya dalam kurun waktu 1 minggu pelaksanaan survei.

Pengambilan data dilakukan dengan menggunakan questioner online dengan bantuan google form yang disebar luaskan menggunakan media WhatsApp Grup, Facebook, dan Twitter. Skala data yang digunakan yaitu skala Likert. Pemilihan alat pengumpulan data melalui google form dapat mempermudah peneliti dalam proses pengumpulan data secara online tanpa harus bertemu secara langsung mengingat keberadaan pandemi Covid-19 yang mengharuskan masyarakat untuk tetap menjaga jarak. Responden dalam penelitian ini adalah individu yaitu masyarakat Nusa Tenggara 
Barat. Sampel yang digunakan dalam penelitian ini sebanyak 342 responden, sesuai dengan jumlah mereka yang merespon survei yang dilakukan.

\section{Hasil dan Pembahasan}

Profil Responden

Tabel 1

Profil Responden

\begin{tabular}{cccccc}
\hline Keterangan & Laki-Laki & $\mathbf{\%}$ & Perempuan & $\mathbf{\%}$ & Total \\
\hline Jenis Kelamin & 205 & $60 \%$ & 137 & $40 \%$ & $100 \%$ \\
\hline Keterangan & PNS & $\mathbf{\%}$ & Non PNS & $\mathbf{\%}$ & Total \\
\hline Jenis Pekerjaan & 181 & $53 \%$ & 161 & $47 \%$ & $100 \%$ \\
\hline Keterangan & $<\mathbf{3 5}$ Tahun & $\mathbf{\%}$ & $\geq \mathbf{3 5}$ Tahun & $\mathbf{\%}$ & Total \\
\hline Kelompok Usia & 79 & $23 \%$ & 263 & $77 \%$ & $100 \%$ \\
\hline Keterangan & $\leq$ SMP & $\mathbf{\%}$ & $\geq$ SMA & $\mathbf{\%}$ & Total \\
\hline Jenjang Pendidikan & 24 & $7 \%$ & 170 & $93 \%$ & $100 \%$ \\
\hline Keterangan & Perdesaan & $\mathbf{\%}$ & Perkotaan & $\mathbf{\%}$ & Total \\
\hline Tempat Tinggal & 99 & $29 \%$ & 243 & $71 \%$ & $100 \%$ \\
\hline
\end{tabular}

Sumber Data Diolah oleh Peneliti Berdasarkan hasil survei

Berdasarkan tabel 1 diketahui dari total 342 responden, diperoleh informasi awal mengenai profil responden dilihat dari indikator jenis kelamin bahwa sebanyak $60 \%$ berjenis kelamin laki-laki atau sebanyak 205 responden dan $40 \%$ berjenis kelamin perempuan perempuan atau sebanyak 137 responden. Jika dilihat dari jenis pekerjaannya, sebanyak 181 responden bekerja sebagai PNS atau 53\% dari seluruh responden dan sebanyak 161 responden bekeja sebagai Non PNS atau 47\% dari jumlah keseluruhan responden. Berdasarkan indikator kelompok usia responden dengan usia dibawah 35 tahun sebanyak 79 atau sebanyak 23\% dari jumlah responden sedangkan kelompok usia yang berada diatas 35 tahun sebanyak 263 responden atau sebesar $77 \%$ dari seluruh jumla responden. Berdasarkan jenjang pendidikan dapat dilihat bahwa dari 342 responden terdapat 24 responden atau $7 \%$ yang memiliki jenjang pendidikan setara SMP atau kebawah dan sebanyak 318 responden atau 93\% yang memiliki jenjang pendidikan setara SMA keatas. Sedangkan berdasarkan tempat tinggal, dari 342 responden menunjukkan bahwa sebanyak 53 responden atau $29 \%$ berasal dari perdesaan dan sebanyak 243 responden atau $71 \%$ berasal dari perkotaan.

\section{Pendapatan Mengalami Penurunan Sejak Pandemi Covid 19}

Penularan yang cepat dan jumlah korban jiwa yang terus berjatuhan membuat pemerintah Indonesia melakukan kebijakan-kebijakan yang dapat mengurangi jumlah angka positif maupun korban jiwa. Beberapa kebijakan seperti Pembatasan Sosial Berskala Besar (PSBB), bahkan hingga karantina wilayah membuat ruang gerak masyarakat terbatasi bahkan aktivitas sosial ekonomi juga terhambat. Tidak sedikit karyawan yang diberhentikan dalam pekerjaannya karena ekonomi sedang turun. Berdasarkan hasil survei lapangan di daerah NTB dalam melihat dampak pandemi Covid-19 
terhadap kehidupan ekonomi masyarakat NTB. Salah satunya yaitu perubahan pendapatan sejak pandemi Covid-19. Berdasarkan hasil survei diperoleh hasil sebagai berikut:

Tabel 2.

Jenis Pekerjaan dan Pendapatan Mengalami Penurunan

\begin{tabular}{ccccccccc}
\hline Jenis & Tidak & & & & & & & \\
Pekeriaan & Setuju & \% & Netral & \% & Setuju & \% & Total & \% \\
\hline PNS & 26 & $14 \%$ & 42 & $23 \%$ & 115 & $63 \%$ & 183 & $100 \%$ \\
Non PNS & 21 & $13 \%$ & 21 & $13 \%$ & 117 & $74 \%$ & 159 & $100 \%$ \\
Total & 47 & $14 \%$ & 63 & $18 \%$ & 232 & $68 \%$ & 342 & $100 \%$ \\
\hline
\end{tabular}

Sumber Data Diolah Berdasarkan hasil survei

Berdasarkan tabel 2 diketahui bahwa sebagian besar responden mengatakan setuju pada masa pandemi Covid-19 pendapatannya menurut. Hal ini terlihat dari 63\% responden PNS yang menyatakan setuju dan sekitar 74\% Non PNS responden menyatakan setuju. Artinya, mereka yang terdampak penurunan pendapatan ini tidak saja mereka yang PNS tapi juga yang Non PNS. Dengan kata lain, antara PNS dan Non PNS memiliki kecenderungan yang sama terkait dengan penurunan pendapatan selama pandemi Covid-19. Hal ini disebabkan karena hampir semua sektor menjadi terdampak akibat merebaknya pandemi Covid-19.

Tabel 3.

Tempat tinggal dan Pendapatan Mengalami Penurunan

\begin{tabular}{ccccccccc}
\hline $\begin{array}{c}\text { Tempat } \\
\text { Tinggal }\end{array}$ & $\begin{array}{c}\text { Tidak } \\
\text { Setuju }\end{array}$ & $\mathbf{\%}$ & Netral & $\mathbf{\%}$ & Setuju & $\mathbf{\%}$ & Total & \% Total \\
\hline Perdesaan & 12 & $12 \%$ & 11 & $11 \%$ & 77 & $77 \%$ & 100 & $100 \%$ \\
Perkotaan & 35 & $14 \%$ & 52 & $21 \%$ & 155 & $64 \%$ & 242 & $100 \%$ \\
Total & 47 & $14 \%$ & 63 & $18 \%$ & 232 & $68 \%$ & 342 & $100 \%$ \\
\hline
\end{tabular}

Sumber Data Diolah Berdasarkan hasil survei

Berdasarkan hasil survei bahwa sebagian besar masyarakat setuju pendapatannya menurun pada masa Pandemi Covid-19. Diidentifikasi menurut tempat tinggal, masyarakat yang bertempat tinggal di perdesaan menjawab bahwa setuju pendapatannya menurun sebanyak $77 \%$ responden sedangkan masyarakat yang bertempat tinggal di perkotaan menyatakan setuju sebanyak $64 \%$ responden. Artinya masyarakat yang bertempat tinggal di Perdesaan dan Perkotaan memiliki kecenderungan yang sama terkait dengan penurunan pendapatan. Hal ini menjadi rasional sebab Covid-19 melanda hampir diseluruh daerah, tak terkecuali dengan daerah yang berada di Perdesaan maupun Perkotaan. 


\section{Lapangan Pekerjaan Terbatas}

Selain menurunnya pendapatan yang diakibatkan oleh Pandemi Covid-19, dampak ekonomi juga dirasakan terkait dengan jumlah lapangan pekerjaan yang tersedia. Berdasarkan hal tersebut maka indikator untuk melihat dampak ekonomi adalah dengan melihat lapangan pekerjaan yang tersedia. Menurut hasil survei dengan karakteristik responden sebagai pekerja PNS dan Non PNS maka ditemukan hasil sebagai berikut:

\section{Tabel 4}

Jenis Pekerjaan dan Persepsi tentang Lapangan Pekerjaan Terbatas

\begin{tabular}{ccccccccc}
\hline $\begin{array}{c}\text { Jenis } \\
\text { Pekerjaan }\end{array}$ & $\begin{array}{c}\text { Tidak } \\
\text { Setuju }\end{array}$ & $\mathbf{\%}$ & Netral & $\mathbf{\%}$ & Setuju & $\mathbf{\%}$ & Total & $\%$ \\
\hline PNS & 11 & $6 \%$ & 29 & $16 \%$ & 115 & $63 \%$ & 183 & $100 \%$ \\
Non PNS & 17 & $11 \%$ & 19 & $12 \%$ & 117 & $74 \%$ & 159 & $100 \%$ \\
Total & 28 & $8 \%$ & 48 & $14 \%$ & 232 & $68 \%$ & 342 & $100 \%$ \\
\hline
\end{tabular}

Sumber Data Diolah Berdasarkan hasil survey

Berdasarkan hasil survei seperti tertera dalam tabel 4 menunjukkan bahwa sebagian besar masyarakat setuju bahwa lapangan pekerjaan menjadi terbatas selama pandemi Covid-19. Hal ini terlihat dari jawaban responden yang menyatakan setuju sebanyak $63 \%$ responden dari responden yang bekerja sebagai PNS, sedangkan Non PNS sebagian besar mengatakan setuju juga bahwa lapangan pekerjaan terbatas selama pandemi Covid-19, ditunjukkan dengan jawaban responden sebanyak 74\% responden menyatakan setuju. Artinya, dari latar belakang pekerjaaan PNS maupun Non PNS cenderung memiliki persepsi yang sama terkait dengan lapangan pekerjaan yang terbatas selama Pandemi Covid-19. Indikator yang sama juga dilihat dari karakteristik responden berdasarkan tempat tinggal yakni masyarakat yang tinggal di perdesaan dan masyarakat yang tinggal di perkotaan

\section{Tabel 5}

Tempat tinggal dan Lapangan Pekerjaan Terbatas

\begin{tabular}{ccccccccc}
\hline $\begin{array}{c}\text { Tempat } \\
\text { Tinggal }\end{array}$ & $\begin{array}{c}\text { Tidak } \\
\text { Setuju }\end{array}$ & $\mathbf{\%}$ & Netral & $\mathbf{\%}$ & Setuju & $\mathbf{\%}$ & Total & $\%$ \\
\hline Perdesaan & 6 & $6 \%$ & 10 & $10 \%$ & 77 & $77 \%$ & 100 & $100 \%$ \\
Perkotaan & 22 & $9 \%$ & 38 & $16 \%$ & 155 & $64 \%$ & 242 & $100 \%$ \\
Total & 28 & $8 \%$ & 48 & $14 \%$ & 232 & $68 \%$ & 342 & $100 \%$ \\
\hline
\end{tabular}

Sumber Data Diolah Berdasarkan hasil survey

Berdasarkan dari hasil survei menunjukkan responden yang bertempat tinggal di perdesaan menyatakan setuju sebanyak $77 \%$ dan responden yang tinggal di perkotaan yang menyatakan setuju sebanyak 64\%; artinya sebagian besar responden setuju bahwa lapangan pekerjaan terbatas selama pandemi Covid-19. Dapat disimpulkan bahwa antara masyarakat yang bertempat tinggal di perdesaan dan perkotaan cenderung mengatakan hal yang sama. 


\section{Pendapatan yang diterima bisa mencukupi kebutuhan sehari-hari}

Untuk melihat dampaknya terhadap kehidupan ekonomi di NTB maka indikator selanjutnya adalah terkait dengan pemenuhan kebutuhan yaitu apakah pendapatan masyarakat selama masa Pandemi Covid-19 dapat memenuhi kebutuhan hidup sehari-hari. Hasil survei dilihat berdasarkan jenis pekerjaan responden yaitu PNS dan Non PNS.

Tabel 6

Jenis Pekerjaan dan Pendapatan yang diterima mencukupi kebutuhan

\begin{tabular}{ccccccccc}
\hline $\begin{array}{c}\text { Jenis } \\
\text { Pekerjaan }\end{array}$ & $\begin{array}{c}\text { Tidak } \\
\text { Setuju }\end{array}$ & $\begin{array}{c}\text { \% Tidak } \\
\text { Setuju }\end{array}$ & Netral & $\begin{array}{c}\text { Netral } \\
\text { Setuju }\end{array}$ & \% Setuju & Total & \% Total \\
\hline PNS & 24 & $13 \%$ & 61 & $33 \%$ & 115 & $63 \%$ & 183 & $100 \%$ \\
Non PNS & 43 & $27 \%$ & 49 & $31 \%$ & 117 & $74 \%$ & 159 & $100 \%$ \\
Total & 67 & $20 \%$ & 110 & $32 \%$ & 232 & $68 \%$ & 342 & $100 \%$ \\
\hline
\end{tabular}

Sumber Data Diolah Berdasarkan hasil survei

Berdasarkan hasil survei yang dilakukan menunjukan bahwa meskipun pada masa Pandemi Covid-19 sebagian masyarakat masih bisa mencukupi kebutuhan hidup sehari hari. Hal ini ditunjukkan berdasarkan tabel tersebut bahwa responden yang bekerja sebagai PNS menyatakan setuju sebanyak 63\% respondens dan responden yang bekerja Non PNS menyatakan setuju sebanyak 74\%. Akan tetapi terkait dengan jawaban tidak setuju, yang menunjukkan bahwa penghasilan yang diperoleh tidak bisa mencukupi kehidupan sehari-hari adalah berturut-turut $13 \%$ dari kalangan PNS dan 27\% dari kalangan Non PNS. Ini artinya, jumlah mereka yang dari kalangan Non PNS lebih besar mengalami kekurangan dalam masa pandemi ini untuk memenuhi kehidupan sehar-hari. Sementara dari kalangan PNS prosentasenya adalah 13\%. Selain itu juga dilihat berdasarkan tempat tinggal responden yaitu perdesaan dan perkotaan maka ditemukan hasil sebagai berikut:

Tabel 7

Tempat tinggal dan Pendapatan mencukupi kebutuhan

\begin{tabular}{ccccccccc} 
Tempat & Tidak & & & & & & \\
Tinggal & Setuju & \% & Netral & \% & Setuju & $\%$ & Total & \% \\
\hline Perdesaan & 30 & $30 \%$ & 27 & $27 \%$ & 77 & $77 \%$ & 100 & $100 \%$ \\
Perkotaan & 37 & $15 \%$ & 83 & $34 \%$ & 155 & $64 \%$ & 242 & $100 \%$ \\
Total & 67 & $20 \%$ & 110 & $32 \%$ & 232 & $68 \%$ & 342 & $100 \%$ \\
\hline
\end{tabular}

Sumber Data Diolah Berdasarkan hasil survey

Berdasarkan hasil survei pada tabel 7 menunjukan masyarakat masih mampu memenuhi kebutuhan hidup sehari-hari dengan pendapatannya saat ini. Pada masyarakat pedesaaan yang menyatakan setuju sebanyak $77 \%$ dan pada masyarakat di perkotaan yang menyatakan setuju sebanyak $64 \%$. Artinya, antara masyarakat di perdesaan dibandingkan dengan perkotaan tidak jauh 
beda. Meskipun dalam keadaan pandemi dan pendapatan mereka cenderung mengalami penurunan, namun masih tetap bisa survive untuk mencukupi kebutuhan sehari-hari.

\section{Pengeluaran Lebih Besar Sejak Pandemi Covid-19}

Kehidupan ekonomi masyarakat selain pendapatan, maka pengeluaran juga akan dilihat. Pengeluaran untuk kehidupan ekonomi keluaraga apakah lebih besar pada masa pandemi Covid-19 ataukah tidak. Indkator survei dilihat pada karakteristik responden yaitu jenis pekerjaannya anara lain PNS dan non PNS, maka ditemukan hasil sebagai berikut:

\section{Tabel 8}

\section{Jenis Pekerjaan dan Peningkatan Pengeluaran Sejak Pandemi}

\begin{tabular}{crrrrrrrr} 
Jenis & Tidak & \% Tidak & & \multicolumn{1}{c}{ \% } & & & \\
Pekerjaan & Setuju & Setuju & Netral & Netral & Setuju & \% Setuju & Total & \% Total \\
\hline PNS & 33 & $18 \%$ & 45 & $25 \%$ & 115 & $63 \%$ & 183 & $100 \%$ \\
Non PNS & 31 & $19 \%$ & 28 & $18 \%$ & 117 & $74 \%$ & 159 & $100 \%$ \\
Total & 64 & $19 \%$ & 73 & $21 \%$ & 232 & $68 \%$ & 342 & $100 \%$ \\
\hline
\end{tabular}

Sumber Data Diolah Berdasarkan hasil survei

Berdasarkan tabel 8 ditemukan hasil bahwa sebagian besar responden baik yang PNS maupu Non PNS setuju pengeluaran lebih besar sejak pandemi Covid-19. Pada responden yang bekerja sebagai PNS menyatakan setuju sebanyak 63\% responden sedangkan pada responden non PNS menyatakan setuju sebanyak 74\%. Artinya, selama Pandemi Covid-19 responden yang berlatar belakang sebagai PNS dan Non PNS cenderung mengalami peningkatan pengeluaran. Selanjutnya dilihat pada masyarakat berdasarkan tempat tinggal yakni masyarakat perdesaan dan masyarakat perkotaan, maka didapatkan data sebagai berikut:

Tabel 9

\section{Tempat Tinggal dan Peningkatan Pengeluaran Sejak Pandemi}

\begin{tabular}{|c|c|c|c|c|c|c|c|c|}
\hline \multirow[b]{2}{*}{$\begin{array}{l}\text { Tempat } \\
\text { Tinggal }\end{array}$} & \multirow[b]{2}{*}{$\begin{array}{r}\text { Tidak } \\
\text { Setuju }\end{array}$} & \multirow[b]{2}{*}{$\%$} & \multirow[b]{2}{*}{ Netral } & \multirow[b]{2}{*}{$\%$} & \multirow[b]{2}{*}{ Setuju } & \multirow[b]{2}{*}{$\%$} & \multirow[b]{2}{*}{ Total } & \\
\hline & & & & & & & & $\%$ \\
\hline Perdesaan & 15 & $15 \%$ & 17 & $17 \%$ & 77 & $77 \%$ & 100 & $100 \%$ \\
\hline Perkotaan & 49 & $20 \%$ & 56 & $23 \%$ & 155 & $64 \%$ & 242 & $100 \%$ \\
\hline Total & 64 & $19 \%$ & 73 & $21 \%$ & 232 & $68 \%$ & 342 & $100 \%$ \\
\hline
\end{tabular}

Sumber Data Diolah Berdasarkan hasil survei

Berdasarkan hasil survei maka ditemukan bahwa sebanyak 77\% responden dari daerah perdesaan menyatakan setuju pengeluaran lebih besar pada masa pandemi Covid-19. Sedangkan pada daerah perkotaan sebanyak 64\% masyarakat responden yang menjadi sampel menyatakan setuju pengeluaran lebih besar pada masa pandemi Covid-19. Artinya, baik masyarakat di perdesaan maupun perkotaan memiliki kecenderungan yang sama dalam hal peningkatan pengeluaran. Hal ini menunjukan bahwa pandemi Covid- 19 yang terjadi bukan hanya mengakibatkan terjadinya 
penurunan pendapatan. Melainkan juga mengakibatkan terjadinya peningkatan pengeluaran. Sehingga diperlukan beberapa upaya yang harus dilakukan supaya masyarakat dapat tetap bertahan memenuhi kebutuhan hidupnya sehari-hari.

\section{Sejak Pandemi Belanja Online Menjadi Pilihan}

Pandemi Covid-19 yang menganjurkan masyarakat untuk tetap di rumah, menjaga jarak sosial (social distancing), dan menjaga jarak fisik (physical distancing) mengakibatkan aktivitas- aktivitas yang berkaitan dengan pertemuan secara langsung (offline) dibatasi, aktivitas tersebut digantikan dengan cara daring (online) untuk mengurangi kontak fisik dengan orang lain. Aktivitas ekonomi juga seperti itu, dianjurkan untuk tidak terlalu sering keluar rumah untuk kegiatan berbelanja. Yang menjadi pertanyaan adalah, apakah sejak pandemi belanja online menjadi pilihan masyarakat. Berdasarkan jenis pekerjaan yaitu PNS dan Non PNS melihat prilaku belanja online masyarakat maka didapat hasilnya sebagai berikut.

Tabel 10

Jenis Pekerjaan dan Belanja Online

\begin{tabular}{ccccccccc}
$\begin{array}{c}\text { Jenis } \\
\text { Pekerjaan }\end{array}$ & $\begin{array}{c}\text { Tidak } \\
\text { Setuju }\end{array}$ & $\%$ & Netral & \% & Setuju & \% & Total & $\%$ \\
\hline PNS & 23 & $13 \%$ & 36 & $20 \%$ & 115 & $63 \%$ & 183 & $100 \%$ \\
Non PNS & 21 & $13 \%$ & 45 & $28 \%$ & 117 & $74 \%$ & 159 & $100 \%$ \\
Total & 44 & $13 \%$ & 81 & $24 \%$ & 232 & $68 \%$ & 342 & $100 \%$ \\
\hline
\end{tabular}

Sumber Data Diolah Berdasarkan hasil survei

Berdasarkan hasil survei menunjukkan bahwa masyarakat yang bekerja sebagai PNS menyatakan setuju akan kebiasaan untuk belanja online pada masa pandemi, sebanyak $63 \%$ responden menyatakan setuju, selanjunya bagi yang Non PNS sebanyak 74\% responden menyatakan setuju terkait pilihan belanja online. Artinya, selama pandemi Covid-19 ini, kecenderungan untuk belanja online relatif sama besar, antara mereka yang PNS dan yang Non PNS. Selain itu juga dilihat berdasarkan tempat tinggal yaitu masyarakat perdesaan dan perkotaan, maka ditemukan hasil sebagai berikut:

\section{Tabel 11}

Tempat Tinggal dan Belanja Online

\begin{tabular}{|c|c|c|c|c|c|c|c|c|}
\hline $\begin{array}{l}\text { Tempat } \\
\text { Tinggal }\end{array}$ & $\begin{array}{r}\text { Tidak } \\
\text { Setuju }\end{array}$ & $\%$ & Netral & $\%$ & Setuju & $\%$ & Total & $\%$ \\
\hline Perdesaan & 19 & $19 \%$ & 28 & $28 \%$ & 77 & $77 \%$ & 100 & $100 \%$ \\
\hline Perkotaan & 25 & $10 \%$ & 53 & $22 \%$ & 155 & $64 \%$ & 242 & $100 \%$ \\
\hline Total & 44 & $13 \%$ & 81 & $24 \%$ & 232 & $68 \%$ & 342 & $100 \%$ \\
\hline
\end{tabular}

Sumber Data Diolah Berdasarkan hasil survei 
Berdasarkan tabel 11 maka ditemukan hasil bahwa sebanyak 77\% masyarakat perdesaan juga memilih untuk belanja online pada masa pandemi Covid-19, sedangkan pada masyarakat perkotaan sebanyak $68 \%$ memilih belanja online. Artinya tingkat aktivitas ekonomi masyarakat lebih banyak dengan online, baik yang tinggal di perkotaan maupun yang di perdesaan.

\section{Pembelian bahan makanan mendominasi pengeluaran sehari-hari}

Pada masa pandemi Covid-19 belanja darahkan pada kebutuhan sehari-hari seperti makanan. Hal ini disebabkan karena aktivitas masyarakat dalam masa pandemic ini lebih banyak dilakukan dari rumah. Oleh karena itu indikator selanjutnya adalah apakah masyarakat mengalihkan belanjanya ke kebutuhan bahan makanan untuk pengeluaran sehari-hari Karakteristik responden yang dilihat adalah pada jenis pekerjaan yaitu PNS dan Non PNS, maka didapatkan hasil sebagai berikut: 
Tabel 12

Jenis Pekerjaan dan Pembelian Bahan Makanan

\begin{tabular}{ccccccccc}
$\begin{array}{c}\text { Jenis } \\
\text { Pekerjaan }\end{array}$ & $\begin{array}{c}\text { Tidak } \\
\text { Setuju }\end{array}$ & $\%$ & Netral & $\%$ & Setuju & $\%$ & Total & $\%$ \\
\hline PNS & 9 & $5 \%$ & 29 & $16 \%$ & 115 & $63 \%$ & 183 & $100 \%$ \\
Non PNS & 7 & $4 \%$ & 28 & $18 \%$ & 117 & $74 \%$ & 159 & $100 \%$ \\
Total & 16 & $5 \%$ & 57 & $17 \%$ & 232 & $68 \%$ & 342 & $100 \%$ \\
\hline
\end{tabular}

Sumber Data Diolah Berdasarkan hasil survey

Berdasarkan tabel 12 maka dapat dilihat bahwa sebagian masyarakat setuju pembelian makanan mendominasi kebutuhan sehari hari-hari. Pada masyarakat yang bekerja sebagai PNS sebanyak $63 \%$ setuju akan hal tersebut sedangkan pada masyarakat yang bekerja diluar PNS atau non PNS, sebanyak 74\% setuju bahwa pembelian makanan mendominasi kebutuhan sehari hari. Selain itu karakteristik responden yang dilihat adalah bedasarkan tempat tinggalnya yaitu pedesaaan dan perkotaan, maka didapat hasil sebagai berikut:

\section{Tabel 13}

Tempat Tinggal dan Pembelian Bahan Makanan

\begin{tabular}{ccccccccc} 
Tempat & Tidak & & & & & & & \\
Tinggal & Setuju & $\%$ & Netral & \% & Setuju & \% & Total & $\%$ \\
\hline Perdesaan & 7 & $7 \%$ & 17 & $17 \%$ & 77 & $77 \%$ & 100 & $100 \%$ \\
Perkotaan & 9 & $4 \%$ & 40 & $17 \%$ & 155 & $64 \%$ & 242 & $100 \%$ \\
Total & 16 & $5 \%$ & 57 & $17 \%$ & 232 & $68 \%$ & 342 & $100 \%$ \\
\hline
\end{tabular}

Sumber Data Diolah Berdasarkan hasil survei

Berdasarkan data hasil survei menunjukkan bahwa 77\% masyarakat pedesaaan setuju bahwa kebutuhan sehari-hari mendominasi kebutuhan sehari-hari sedangkan pada masyarakat perkotaan sebanyak 64\% yang setuju. Artinya sebagian besar masyarakat berdasarkan hasil survei menyatakan setuju kebutuhan makanan yang mendominasi kebutuhan sehari-hari.

\section{Perlu dilakukan efisiensi dalam pengeluaran sehari-hari}

Rendahnya pendapatan dan pegeluaran sehati-hari untuk memenuhi kebutuhan. Oleh karena itu indikator selanjutnya adalah apakah perlu dilakukan efisiensi dalam peneluaran sehari- hari. Karakteristik responden yang dilihat adalah pada bidang pekerjaan yaitu PNS dan Non PNS, maka didapat hasil sebagai berikut. 
Tabel 14

Jenis Pekerjaan dan Efisiensi pengeluaran sehari-hari

\begin{tabular}{ccccccccc}
\hline $\begin{array}{c}\text { Jenis } \\
\text { Pekerjaan }\end{array}$ & $\begin{array}{c}\text { Tidak } \\
\text { Setuju }\end{array}$ & \% & Netral & \% & Setuju & $\%$ & Total & $\%$ \\
\hline PNS & 4 & $2 \%$ & 15 & $8 \%$ & 115 & $63 \%$ & 183 & $100 \%$ \\
Non PNS & 7 & $4 \%$ & 20 & $13 \%$ & 117 & $74 \%$ & 159 & $100 \%$ \\
Total & 11 & $3 \%$ & 35 & $10 \%$ & 232 & $68 \%$ & 342 & $100 \%$ \\
\hline
\end{tabular}

Sumber Data Diolah Berdasarkan hasil survey

Berdasarkan data tersebut maka dapat ditarik hasil bahwa pada responden yang bekerja sebagai PNS menyatakan setuju sebanyak 63\% sedangkan yang non PNS yang menyatakan setuju sebanyak 74\%. Artinya sebagaian besar responden setuju akan perlunya efisiensi dalam pengeluaran sehari-hari. Selain itu indikator yang sama dilihat juga berdasarkan tepat tinggal seperti perdesaan dan perkotaan, maka didapatkan hasil sebagai berikut:

Tabel 15

Tempat Tinggal dan Efisiensi Pengeluaran

\begin{tabular}{|c|c|c|c|c|c|c|c|c|}
\hline $\begin{array}{c}\text { Tempat } \\
\text { Tinggal }\end{array}$ Sidak & & & & & & \\
\hline Petuju & $\%$ & Netral & $\%$ & Setuju & $\%$ & Total & $\%$ \\
\hline Perkotaan & 4 & $4 \%$ & 11 & $11 \%$ & 77 & $77 \%$ & 100 & $100 \%$ \\
\hline Total & 11 & $3 \%$ & 24 & $10 \%$ & 155 & $64 \%$ & 242 & $100 \%$ \\
\hline
\end{tabular}

Sumber Data Diolah Berdasarkan hasil survey

Berdasarkan hasil data tersebut jumlah masyarakat yang setuju sebanyak $77 \%$ berada di wilayah perdesaan dan di wilayah perkotaan jumlah masyarakat yang setuju sebanyak $64 \%$. Artiya sebagian besar masyarakat setuju bahwa perlunya efisiensi dalam pengeluaran sehari-hari. Hal ini penting supaya perekonomian keluarga tetap dapat survive di masa Pandemi Covid-19.

\section{Pembahasan}

Pada temuan data yang telah diuraikan diatas menunjukan bahwa masyarakat melakukan adaptation atau adaptasi dalam hal ekonomi di masa pandemi Covid-19 dengan cara menghemat atau melakukan efisiensi pengeluaran. Efisiensi pengeluaran dilakukan oleh masyarakat di masa Pandemi Covid-19 guna mengantisipasi kemungkinan terburuk seperti menurunnya pendapatan, terjadinya peningkatan pengeluaran dan kemungkinan terkena PHK hingga sempitnya lapangan pekerjaan. Ritzer (2010) yang mengungkapkan bahwa sebuah sistem harus mampu menanggulangi situasi eksternal yang gawat. Sistem harus mampu menyesuaikan diri dengan lingkungan dan menyesuaikan lingkungan dengan kebutuhannya. Sehingga antara masyarakat yang bekerja sebagai PNS maupun Non PNS dan masyarakat yang berasal dari perdesaan maupun perkotaan cenderung memiliki 
jawaban yang sama untuk melakukan efisiensi pengeluaran. Hal ini dilakukan guna menyelaraskan pendapatan yang menurun di satu sisi dan di sisi lain terjadinya peningkatan pengeluaran. Dengan penerapan strategi seperti ini tentu yang diharapkan terjadi adalah perekonomian keluarga tetap berjalan dan kebutuhan keluarga dapat tetap terpenuhi. Fenomena ini sejalan dengan temuan Sakri (2020) yang menyimpulkan bahwa dampak pandemic terhadap perekonomian masyarakat sangat signifikan. Bahkan di paparkan dalam tulisan tersebut (Sakri, 2020) yang mengutip hasil dari Survei online JPAL dan UI yang menyatakan bahwa 56 responden yang di menjadi responden menyatakan bahwa mereka tidak lagi bekerja pada minggu ke delapan sejak Pandemi terjadi. Artinya adalah bahwa penyelarasan pendapatan dengan pengeluaran selama masa pandemic harus dilakukan.

Pada tahap Goal Attainment, masyarakat mencoba untuk mengatur dan menyusun sebuah tujuan masa depan dan mengambil keputusan sesuai tujuan tersebut (Sairoh, 2017). Guna mencapai keselamatan ekonomi dan terjaganya kesehatan maka masyarakat yang bekerja sebagai PNS maupun Non PNS serta masyarakat yang berasal dari perdesaan dan perkotaan cenderung memilih melakukan belanja secara online. Hal ini bertujuan untuk mengantisipasi terjadinya penularan Covid-19. Sehingga belanja online menjadi pilihan yang diambil oleh sebagian besar masyarakat yang menjadi responden dalam penelitian ini. Hal lain juga terlihat ketika sebagian besar masyarakat mengatakan bahwa pembelian makanan mendominasi pengeluaran mereka. Sebagai kebutuhan pokok, makanan tentu menjadi prioritas utama yang harus dipenuhi oleh masyarakat. Sebagian besar responden mengatakan bahwa pengeluaran mereka didominasi oleh pembelian bahan makanan dari pada untuk membeli kebutuhan lainnya. Hal ini sesuai dengan anjuran para pakar ekonomi yang berpendapat agar dalam masa yang tidak menentu seperti ini maka belanja yang sifatnya investasi ditunda dulu untuk sementara (Thaha, 2020; Sayuti, 2020; Dani, 2020). Sumberdana yang dimiliki hendaknya diarahkan atau dibatasi untuk belanja kebutuhan hidup sehari-hari. Tujuannya adalah agar jangan sampai masyarakat yang telah terdampak secara sosial dengan adanya pandemi ini akan mengalami persoalan ekonomi di kemudian hari akibat dari investasi yang kemudian tidak dapat berjalan sesuai dengan yang diharapkan. Keadaan ini juga untuk mengantisipasi terjadinya food insecurity seperti yang disinyalir dalam temuan Sakri (2020) dalam survei yang dilaksanakan pasca merebaknya Pandemi di awal Maret 2020. Temuan dalam penelitian tersebut menunjukkan 35\% dari responden yang disurvei menyatakan bahwa volume makanan yang dibeli mengalami penurunan sebagai akibat dari menurunnya pendapatan atau daya beli mereka.

Selanjutnya yaitu tahap Integration dimana terjadinya tindakan saling koordinasi antar hubungan unit-unit sistem yang ada seperti sistem budaya, sosial dan organisasi. Salah satunya kemudian mengakibatkan perekonomian masyarakat menjadi terhambat. Integration menjadi sangat penting karena satu sama lain saling mempengaruhi. Disamping menjaga kesehatan dan terhindar dari Covid-19 hal yang tak kalah penting adalah menjaga perekonomian keluarga tetap 147 | RESIPROKAL: Jurnal Riset Sosiologi Progresif Aktual 
dalam keadaan yang baik. Mengintegrasikan antara turunnya pendapatan dengan meningkatnya pengeluaran menjadi fenomena tersendiri yang menjadi solusi untuk survive di masa pandemi seperti ini. Jika hal ini tidak dilakukan maka bukan tidak mungkin akan terjadi peningkatan angka kemiskinan. Suryahadi et. al. (2020) memperkirakan secara nasional akan terjadi peningkatan prosentase jumlah penduduk miskin di Indonesia, dari 9,2\% pada September 2019, menjadi 9,7\% pada September 2020.

Tahap terakhir Latency atau pemeliharaan pola yaitu masyarakat harus saling melengkapi, memelihara dan memperbaiki, baik motivasi individual maupun pola-pola kultural yang menciptakan dan menopang motivasi. Setelah masyarakat mampu beradaptasi dan mencapai tujuan untuk mempertahankan pondasi ekonomi mereka maka langkah selanjutnya adalah mempertahankan pola baru yang sudah terbentuk. Hal ini bertujuan untuk mempertahankan sistem supaya tetap bertahan dan tidak ambruk. Berdasarkan berbagai literatur yang ada (Azimah, 2020; Kickbusch, 2020; Honoatubun, 2020) diperoleh suatu kesimpulan bahwa pandemi ini menyebabkan terpengaruhnya kehidupan sosial dan ekonomi masyarakat. Terjadi suatu perubahan perilaku sosial dan ekonomi pada masyarakat untuk dapat mempertahankan diri dari keadaan yang tidakmenentu dan cenderung berkepanjangan. Ada pola baru yang kemudian terbentuk. Pola baru ini yang kemudian oleh (Sayuti, 2020) disebutkan sebagai masyarakat menghadapi era kenormalan baru (New Normal Era). Fenomena ini dirasakan atau dialami oleh seluruh lapisan masyarakat, apapun pekerjaan yang mereka kerjakan dan dimanapun mereka bertempat tinggal.

Penerapan PSBB selama masa pandemi Covid-19 mengakibatkan perubahan sosial di masyarakat dan menimbulkan dampak secara ekonomi. Hal ini ditunjukkan oleh hasil penelitian yang menyatakan bahwa sebagian besar responden merasakan dampak pandemi Covid-19 secara ekonomi. Ini dibuktikan oleh jawaban responden yang sebagian besar menyatakan pendapatan yang diterima mengalami penurunan tetapi masih bisa mencukupi kebutuhan sehari-hari, lapangan pekerjaan menjadi terbatas, pengeluaran menjadi lebih besar dan didominasi oleh pembelian bahan makanan. Pembelian yang dilakukan melalui online menjadi pilihan dari responden. Sehingga bisa dinyatakan bahwa pandemi ini berpengaruh signifikan terhadap kehidupan masyarakat, baik mereka yang berlatar belakang PNS maupun non PNS dan mereka yang tinggal di perdesaan dan perkotaan.

\section{Kesimpulan}

Berdasarkan uraian dan pembahasan diatas dapat disimpulkan beberapa hal sebagai berikut: (1) Adanya pandemi Covid-19 yang melanda dunia telah mempengaruhi pola kehidupan ekonomi masyarakat secara signifikan, mulai dari pendapatan yang diterima, pola pengeluaran untuk kehidupan sehari-hari, lapangan pekerjaan, dan kebiasaan belanja yang didominasi oleh belanja untuk makanan dan kehidupan sehari-hari serta adanya kebiasaan baru berbelanja on line. (2) Tidak ditemukan adanya perbedaan yang signifikan antara mereka yang berstatus sebagai PNS maupun yang bukan 
PNS. Pengaruh pandemi khsusunya terkait dengan kehidupan ekonomi masyarakat dirasakan hampir merata, baik oleh mereka yang berstatus sebagai PNS maupun yang Non PNS. (3) Khusus terkait dengan penghasilan yang diperoleh, responden dari kalangan Non PNS lebih banyak yang terdampak, dimana penghasilannya menjadi menurun, dibandingkan dengan mereka yang dari kalangan PNS. (4) Berdasarkan segi lokasi tempat tinggal juga dapat disimpuilkan bahwa pengaruh pandemi ini tidak hanya dirasakan oleh mereka yang tinggal di wilayah perkotaan, namun juga mereka yang tinggal di wilayah perdesaan. Untuk mengatasi berbagai persoalan yang dihadapi oleh masyarakat di masa pandemi ini maka disarankan (1) kepada pemerintah untuk lebih kreatif dalam memperbanyak lapangan kerja yang sekaligus tidak memiliki risiko tinggi dalam penyebaran pandemi Covid-19. Berbagai fasilitas usaha yang sifatnya online hendaknya diperbanyak dan dipermudah. (2) Berbagai kebijakan pemerintah juga tidak boleh hanya terfokus di wilayah perkotaan saja, tapi juga hendaknya merata ke wilayah perdesaan, karena mereka yang terdampak pandemi ini tidak hanya mereka yang berada di perkotaan semata.

\section{Daftar Pustaka}

Azimah, Rizki Nor, Ismi Nur Khasanah, Rizky Pratama, Zulfanissa Azizah, Wahyu Febriantoro, Shafa Rifda Syafira Purnomo .2020. Analisis Dampak Covid-19 Terhadap Sosial Ekonomi Pedagang Di Pasar Klaten Dan Wonogiri. EMPATI, Jurnal Kesejahteraan Sosial . Vol. 9 No. 1 Juni 2020.

Dani, JA, 2020. Covid-19 dan Perubahan Komunikasi Sosial. Jurnal Universitas Surakarta, 1 (1): 9697

Damuri dan Hirawan (2020). Mengukur Dampak COVID pada Pertumbuhan Ekonomi dan Perdagangan Indonesia 2020. CSIS Commentaries DMRU- 015. 26 Maret 2020.

Dinas Pariwisata dan Kebudayaan. (2013). Analisis Dampak Sosial-Ekonomi Kawasan Ekonomi Khusus Pariwisata Tanjung Lesung. Provinsi Banten

Ghozali, I. (2011). Aplikasi analisis multivariate dengan program IBM SPSS 19. Semarang : Badan Penerbit Universitas Diponegoro.

Gillin and Gillin. 1950. Cultural Sociology. Rev. $2^{\text {nd }}$ Edition. New York Macmillan.

Grathoff, Richard. 2000. Kesesuaian antara Alfred Schutzdan Talcott Parsons : Teori Aksi Sosial.

Jakarta: Kencana.

Honoatubun, S. (2020). "Dampak Covid-19 Terhadap Perekonomian Indonesia”. EduPsyCouns Journal. 2 (1):151

Kickbusch, I., Leung, G. M., Bhutta, Z. A., Matsoso, M. P., Ihekweazu, C., \& Abbasi, K. (2020). Covid-19: How a Virus is Turning The World Upside Down. Bmj, 1336(April),

Kirigia, J. M., \& Muthuri, R. N. D. K. (2020). The Fiscal Value of Human Lives Lost From Coronavirus Disease (COVID-19) in China. BMC Research Notes, 13(1), 1-5. https://doi.org/10.1186/s13104-020-05044-y

Nasution, Dito. Aditia Darma, Erlina. dan Iskandar Muda, 2020. "Dampak Pandemi Covid-19 Terhadap Perekonomian Indonesia, ” Jurnal Benefita 5(2) Juli 2020

Nursalim, Isnan. 2020. Imunitas Sosial : Gotong Royong Menghadapi Pandemi Covid-19. Sukabumi : Haura Publishing. 
Putri, K. Retno. 2020. Efek Pandemi Covid-19: Dampak Lonjakan Angka PHK Terhadap Penurunan Perekonomian di Indonesia. Jurnal Bismak. Vol.1 No. 1 Maret. Raho, Bernard, SVD. 2007. Teori Sosiologi Modern. Jakarta: Prestasi Pustaka.

Ritzer, George \& Douglas J. Goodman. 2010. TeoriSosiologi Modern. Jakarta: Kencana.

Sairoh, ST. 2017. Perkawinan Dini Perspektif Fungsionalisme Struktural (Studi Kasus di Desa Poreh, Kecamatan Lenteng, Kabupaten Sumenep, Madura). Tesis. Program Magister Ahwal Al Syakhsiyah. Malang : Universitas Islam Negeri Maulana Malik Ibrahim.

Sakri, Diding (2020). "Menakar DampakPandemiCOVID-19 terhadap Perekonomian Daerah." CSIS Commentaries DMRU-088-ID 8 Juli 2020

Sayuti, Rosiady (2020); "Selamat Datang Era New Normal," Koran Harian Lombok Post, 23 Mei 2020.

Sayuti, Rosiady H. 2020. "The Influence of Pandemic Covid-19 on Small Business Enterprise in West Nusa Tenggara Province," Makalah yang dipresentasikan pada The $2^{\text {nd }}$ Annual Conference on Education and Social Sciences. FKIP Universitas Mataram, October 26-27, 2020.

Suryahadi, A., Al Izzati, R., \& Suryadarma, D. (2020). The Impact of COVID-19 Outbreak on Poverty: An Estimation for Indonesia (draft) (SMERU Working Paper). SMERU Working Paper (Vol. April). Jakarta. Retrieved from http://smeru.or.id/en/content/impact-Covid-19-outbreak-povertyestimation- indonesia

Thaha, Abdurrahman Firdaus, 2020. "Dampak Covid-19 terhadap UMKM di Indonesia." Jurnal Brand, Volume 2 No. 1, Juni 2020.

Kompas.co. 2020. Gubernur NTB Umumkan Kasus Positif Corona Pertama di Lombok. Kompas.co (Diakses, 14 Desember 2020) dari https://nasional.tempo.co/read/1323462/gubernur-ntb-umumkan-kasus-positif-coronapertama-di-lombok/full\&view $=$ ok

VOA Indonesia. (n.d.). Menkeu: Dampak Covid-19, Pertumbuhan Ekonomi Indonesia 2020 bisa Minus 0,4 persen. VOA Indonesia. (Diakses, 14 Desember 2020) dari https://www.voaindonesia.com/a/menkeudampak-Covid-19-pertumbuhan- ekonomiindonesia2020-bisa-minus-0-4- persen/5355838.html 